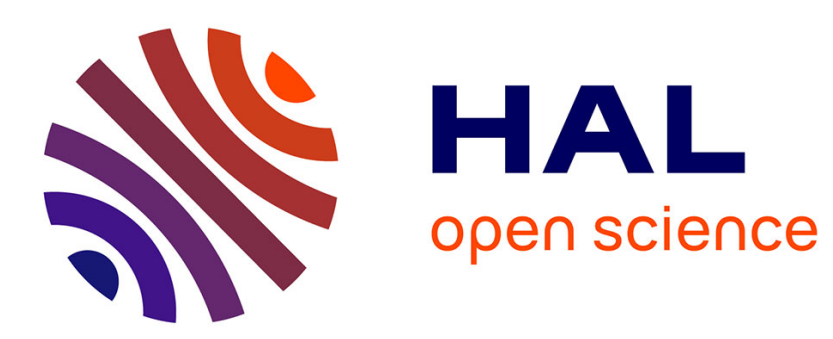

\title{
Matricellular Proteins and Organ Fibrosis
}

Niki Prakoura, Christos Chatziantoniou

\section{To cite this version:}

Niki Prakoura, Christos Chatziantoniou. Matricellular Proteins and Organ Fibrosis. Current Pathobiology Reports, 2017, pp.1-11. 10.1007/s40139-017-0138-6 . hal-01514919

\section{HAL Id: hal-01514919 \\ https://hal.sorbonne-universite.fr/hal-01514919}

Submitted on 26 Apr 2017

HAL is a multi-disciplinary open access archive for the deposit and dissemination of scientific research documents, whether they are published or not. The documents may come from teaching and research institutions in France or abroad, or from public or private research centers.
L'archive ouverte pluridisciplinaire HAL, est destinée au dépôt et à la diffusion de documents scientifiques de niveau recherche, publiés ou non, émanant des établissements d'enseignement et de recherche français ou étrangers, des laboratoires publics ou privés. 


\section{Matricellular proteins and organ fibrosis}

Niki Prakoura, Ph.D. ${ }^{1}$ and Christos Chatziantoniou, Ph.D. ${ }^{1,2}$

${ }^{1}$ Institut National de la Santé Et de la Recherche Médicale UMRS 1155, Tenon Hospital, Paris, France.

${ }^{2}$ Sorbonne Universités, UPMC Paris 6, Paris, France.

Keywords: Matricellular proteins, Fibrosis, Fibroblasts, Extracellular matrix, Targets of therapy, Biomarkers.

All reported studies/experiments with human or animal subjects performed by the authors have been previously published and complied with all applicable ethical standards (including the Helsinki declaration and its amendments, institutional/national research committee standards, and international/national/institutional guidelines).

Correspondence:

Dr. Christos Chatziantoniou,

INSERM UMR S1155, Tenon Hospital, 4 rue de la Chine, 75020 Paris, France.

Email: christos.chatziantoniou@upmc.fr

Tel: (331) 56016653, Fax: (331) 56016659 


\begin{abstract}
Purpose of review: This review intends to outline the novel findings on the effects of matricellular proteins in the development of organ fibrosis and present recent advances towards a potential usage of matricellular proteins as markers or targets of therapy for fibrotic diseases.

Recent findings: Recent studies elucidated the sites of production of different matricellular proteins during fibrosis of several organs, their specific binding receptors and their effects on different cell types. For some proteins, a differential function between chronic disease and acute injury and a connection to regulation of inflammatory cell subtypes with relevance to fibrosis was established.

Summary: Matricellular proteins have evolved as important mediators in the progression of fibrosis. Several studies have already depicted their potential as biomarkers of the disease stage and evolution in patients, while the evaluation of their utility as therapeutic targets has been limited in animal models of fibrosis. This knowledge should guide future research on the development of drugs to treat fibrosis.
\end{abstract}




\section{Introduction}

Matricellular proteins were first described by the team of Paul Bornstein twenty years ago, in order to characterize a family of non-structural proteins secreted in the extracellular matrix (ECM). Some of the most well-known members of the family include CCNs, thrombospondins, osteopontin, periostin, secreted protein acidic and rich in cysteine (SPARC) and tenascins. These proteins are dynamically expressed by several cell types into the ECM, but they do not represent primary structural components of the matrix; instead, they mediate the interaction between cells and their surrounding microenvironment modulating cell function $(1,2)$.

Presently, matricellular proteins are well described to display certain distinct characteristics. First, their expression is tightly regulated, being highly induced during development or under pathological conditions. Secondly, they are capable of interacting with a large variety of matrix proteins, cell-surface receptors and cytokines present in the ECM which accounts in large part for the complexity of their functions. Moreover, most of these proteins fail to support cell adhesion, while they induce an intermediate adhesive state characterized by formation of focal adhesions and stress fibers. Lastly, contrary to the initial anticipation, a targeted disruption of the genes of most matricellular proteins in the mouse presents only a subtle or no apparent phenotype $(1,2)$.

The key function of matricellular proteins to mediate communication and modulate the signaling between cells and their extracellular environment has introduced them as potentially crucial players in several pathophysiological conditions, such as embryogenesis, angiogenesis, cancer or chronic wound healing. This review will summarize the recent findings on matricellular proteins in the field of organ fibrosis by taking a closer look at each 
protein separately in different tissues and models of fibrosis. The advances towards a potential usage of matricellular proteins as therapeutic targets to treat fibrosis will also be discussed.

\section{Wound healing and fibrotic diseases}

Wound repair is a complex fundamental process that takes place in all mammalian tissues after exposure to an injurious stimulus. The normal response to injury comprises of three distinct but overlapping phases: inflammation, new tissue formation and remodeling. Initially, inflammatory pathways are activated and immune cells are recruited at the site of injury in order to prevent blood loss and infections or remove cell debris. In a second time, new tissue formation occurs characterized by re-epithelialization, angiogenesis and granulation tissue formation. At this stage, activated fibroblasts differentiate into myofibroblasts which proliferate and produce high amounts of ECM to support the repair of the damaged tissue. At the last phase, all unnecessary cells undergo apoptosis or exit the wound, while excess matrix is remodeled in the final step to restore the original tissue architecture. However, excessive ECM deposition may occur in case of chronic wound healing which leads to fibrosis, tissue degeneration and dysfunction. The multiple steps linking wound healing to fibrosis are illustrated in Figure 1. Fibrosis plays a major role in the pathology of chronic diseases in many organs; for example, in case of myocardial scar formation after infarction, fibrosis in the liver or the lung after viral infections or toxic injuries, or fibrosis in the kidney triggered by chronic occurrence of diabetes or hypertension $(3,4)$. Although these pathologies can impair tissue function and lead to death, there is still no available treatment targeting fibrosis. Recent findings indicate that several matricellular proteins contribute to tissue remodeling by promoting or inhibiting fibrosis, and therefore may serve as intriguing novel targets of therapy against fibrotic diseases. 


\section{Matricellular proteins in fibrotic diseases}

\section{CCNs}

$\mathrm{CCN}$ proteins comprise a family of six cysteine-rich homologous members that have been denominated CCN1-6 according to international nomenclature. The $\mathrm{CCN}$ acronym was introduced from the names of the first three members of the family that were identified: cysteine-rich 61 (CYR61/CCN1), connective tissue growth factor (CTGF/CCN2) and nephroblastoma overexpressed (NOV/CCN3). The last three members of the family were discovered as Wnt-inducible signaling pathway proteins (WISP) (4).

CCN2 is the most extensively studied member of the family which has been shown to function as a pro-fibrotic mediator in nearly every organ or tissue, including the heart, kidney, liver and lung $(4,5)$. CCN2 was shown to exert its functions through direct activation of cells to produce ECM, induction of cell cycle arrest or hypertrophy, and conversion of resident cells to activated myofibroblasts. CCN2 acts downstream the pro-fibrotic cytokine TGF $\beta$, but it has also been shown to activate or co-activate TGF $\beta$ through binding to cell-surface receptors like tropomyosin-related kinase $\mathrm{A}(\mathrm{TrkA})$ and activation of downstream signaling which prevents the expression of inhibitory $\operatorname{Smad} 7(6,7)$. More recent findings verified the pro-fibrotic role of CCN2 in the $m d x$ mouse model of muscular dystrophy, since hemizygous mice or mice treated with an anti-CTGF monoclonal antibody showed improved muscle strength, reduced apoptotic damage and fibrosis (8). Another study on the same model found that ACE inhibition reduced muscle damage and ECM accumulation by inhibiting the expression of CCN2 (9). Interestingly, RNA interference silencing CCN2 in activated primary cardiac fibroblasts was found to block multiple pro-inflammatory and pro-fibrotic pathways, demonstrating that $\mathrm{CCN} 2$ is a central regulator in these processes (10). 
Contrary to the well-established pro-fibrotic role of $\mathrm{CCN} 2$, the functions of three other members of the family, $\mathrm{CCN} 1, \mathrm{CCN} 3$ and $\mathrm{CCN} 5$, have been rather controversial. These proteins are mainly considered to possess anti-fibrotic functions, however certain studies have also revealed opposite effects. Several recent studies on models of liver fibrogenesis have pinpointed the anti-fibrotic role of CCN1 (11-13). In one study, hepatocyte-specific deletion of $\mathrm{CCN} 1$ exacerbated fibrosis, while $\mathrm{CCN} 1$ overexpression or tail vein delivery of recombinant protein attenuated the fibrotic phenotype. CCN1 was shown to exert this function by triggering ER stress and ROS production in activated hepatic stellate cells (HSCs) to induce cellular senescence and apoptosis. On the other hand, recent findings have shown that CCN1 overexpression through adenovirus-mediated gene transfer in mouse lungs induces acute lung injury evident by increased bronchoalveolar lavage (BAL) neutrophil counts, protein concentrations, weight loss and mortality, while increased CCN1 expression was also observed in biopsies from patients with idiopathic pulmonary fibrosis (IPF) (14). CCN3 has also been shown to play a role in models of hepatic fibrosis, where it was found increased in activated HSCs. In vitro, treatment of cells with pro-fibrotic cytokines suppressed CCN3 expression, while treatment with $\mathrm{CCN} 3$ siRNA enhanced the expression of pro-fibrotic marker proteins (15). In animal models of diabetic nephropathy (DN), intraperitoneal injections with recombinant $\mathrm{CCN} 3$ reduced the renal expression of pro-fibrotic markers and prevented the establishment of glomerular fibrosis and podocyte loss (6). On the contrary, CCN3 $\mathrm{KO}$ mice were protected in the unilateral ureteral obstruction (UUO) model of renal fibrosis, displaying reduced inflammation and fibrosis, while CCN3 was consistently found increased in biopsies of tubulointertitial nephritis patients (16). Lastly, CCN5 may be considered as a natural inhibitor of $\mathrm{CCN} 2$, since it suppresses the expression of $\mathrm{CCN} 2$ in fibroblasts, concomitantly with that of several pro-fibrotic molecules, preventing 
myofibroblast transformation $(5,17,18)$. Overexpression of CCN5 in mouse models of IPF or myocardial fibrosis decreased fibrosis and preserved organ function.

\section{Thrombospondins}

Thrombospondins (TSPs) are highly conserved, multi-domain, calcium-binding glycoproteins of connective tissues. There are five TSP genes in mammals which are divided into two subgroups. TSP1 and TSP2 belonging in subgroup A, represent trimeric proteins with low expression in normal ECM which are transiently induced in tissue injury and remodeling conditions. TSP3, TSP4 and TSP5 are subgroup B TSPs and constitute pentameric highlyabundant components of the ECM in cartilage, bone, tendons and blood vessel walls (19). Interestingly, a recent study revealed the mechanism of recruitment of TSPs into the ECM; their accumulation is controlled by intermolecular interactions through a novel site on the Ltype lectin domain of TSPs, which can take place extracellularly and are concentrationdependent (19).

Most work on the involvement of TSPs in organ fibrosis has been focused on the prototype member of the family, TSP1, in part because of its ability to activate latent TGF- $\beta 1$ and its angiostatic function. A recent study in Col4a3 KO mice which develop spontaneous renal failure revealed that TSP1 deficiency induced a shift from a fibroproliferative to an inflammatory phenotype with less collagen accumulation and reduced activation of latent TGF- $\beta 1$ (20). Separate studies on animal models of renal disease also confirmed the profibrotic role of TSP1. In a high-fat diet mouse model, wild-type obese mice showed increased expression of TSP1 in the kidney and developed albuminurea, renal hypertrophy and fibrosis, while these effects were abrogated in TSP1 KO mice. The authors treated primary isolated mesangial cells with leptin and showed that leptin-stimulated ECM production was abolished 
by TSP1 deficiency (21). Moreover, TSP1 deficiency or treatment with shRNA against TSP1 was protective in mouse UUO, leading to decreased inflammation and fibrosis, increased VEGF expression and preserved endothelial capillary network $(22,23)$. TSP1 was also found to mediate high-fat diet-induced skeletal muscle fibrosis or diabetes-induced myocardial fibrosis by either inducing collagen expression or inhibiting collagen degradation through regulation of MMP2 and MMP9 activities, respectively $(24,25)$.

Several studies have also demonstrated a role for TSP2 in development of fibrosis with, however, contradictory results. In a mouse cardiomyocyte grafting model, lack of TSP2 led to reduced fibrosis and peri-graft scar thickness, while endothelial cell density and cardiomyocyte graft size were increased (26). Moreover, TSP2 was the only TSP increased in fibrosclerotic and stenotic aortic valves of patients with calcific aortic valve disease, expressed in valvular myofibroblasts and neovessels (27). In patients with systemic sclerosis (SSc), TSP2 serum levels were increased and correlated with the severity of the disease. Primary fibroblasts isolated from these patients showed increased expression of TSP2 in their conditioned medium, while TSP2 knock-down inhibited the expression of collagen type I (28). On the contrary, a study on doxorubicin-induced cardiomyopathy revealed opposite effects; TSP2 KO mice showed depressed cardiac function, increased scar formation and cardiomyocyte apoptosis attributed to impaired activation of the Akt pathway (29).

\section{Periostin}

Periostin (Postn) is a $90 \mathrm{kDa}$ secreted protein with adhesive function, mostly abundant in periosteum, periodontal ligament, bone, skin and developing heart. The protein is composed of four fasciclin domains which derive from the insect fasciclin I domain, known to mediate neuronal adhesion. Postn has been shown to directly interact with ECM components like 
collagen I, tenascin-C and fibronectin in order to promote collagen fibrilogenesis, as well as several surface integrins to mediate cell adhesion and migration. The expression of Postn is dynamically regulated being highly induced during development and tissue remodeling, while it is also highly up-regulated by TGF- $\beta 1(30,31)$.

Certain important studies few years ago were the first to indicate the crucial role of Postn during cardiac healing. In mouse acute myocardial infarction (AMI) models, the absence of Postn led to impaired healing and death because of reduced myocardial stiffness and impaired collagen fibrilogenesis. On the other hand, mice surviving infarction or subjected to long-term pressure overload were protected from hypertrophy and fibrosis $(31,32)$. Most recent studies have verified the deleterious effect of Postn in chronic cardiac fibrosis models (33-35). Kaur et al. showed that Postn is the marker with the highest correlation to an activated cardiac fibroblast phenotype, while targeted ablation of Postn-expressing fibroblasts reduced fibrosis and improved cardiac function after AMI or Ang-II exposure (36). Interestingly, another study applied a selective blockade of Postn using a targeted neutralizing antibody, thus linking the deleterious function of Postn in the heart to a specific region of the full-length Postn isoform (37). These results suggest that Postn may play a differential role in acute vs. chronic injury.

Postn was shown to be highly expressed in the lungs of patients with IPF and asthma downstream of IL-13. In animal and in vitro studies, Postn was shown to mediate pulmonary fibrosis by promoting the production of pro-inflammatory cytokines and inducing secretion of collagen by lung fibroblasts (38-40). In recent clinical studies, high serum Postn levels could predict a shortened survival and worsened outcome with increased fibrosis in patients with 
IPF (41). Moreover, clinical trials with type 2 immune response antagonists showed good efficacy in asthmatic patients with high serum Postn levels (42).

We were among the first to discover that Postn was highly induced during chronic kidney disease (CKD) being well correlated with progression or reversal of the disease and with classical indexes of renal function (43). Moreover, we showed that Postn deficiency or antisense delivery against Postn were largely protective in CKD models leading to less inflammation and fibrosis (44). Induction of Postn was attributed to pro-inflammatory pathways, while its deleterious function was linked to activation of integrin signaling (45). In parallel, other studies mainly performed on renal biopsies highlighted the overexpression of Postn in several renal diseases, including focal segmental glomerulosclerosis, mesangial and IgA nephropathy, diabetic nephropathy, lupus nephritis and polycystic kidney disease, also correlating its expression levels with renal function (46-49). On the other hand, the potential role of Postn in acute kidney injury has not been examined yet.

Postn has been also found particularly up-regulated in other fibrotic diseases, like various skin pathologies, muscular dystrophy or liver fibrosis, with $\mathrm{KO}$ mice being protected towards progression of the disease in animal models (50-54). The function of Postn in dermal fibroblasts or HSCs was associated with activation of the cells towards a proliferative and ECM-producing phenotype. Interestingly, in acute versus chronic skeletal muscle injury models Postn showed a similar function as in cardiac healing, being transiently expressed to assist in myotube regeneration or persisting with stable overexpression in fibrotic compartments, respectively (55). In a recent study on a laser-induced choroidal fibrosis model, local application of a new class siRNA against Postn drastically inhibited fibrosis 
formation, indicating the potential utility of Postn-targeting drugs for therapeutic applications towards fibrosis (56).

\section{Osteopontin}

Osteopontin (OPN) is a multifunctional protein abundantly expressed in bone as an organic component, but also expressed by a variety of other tissues and cell types, such as fibroblasts, immune cells, smooth muscle cells, endothelial cells and several epithelial cell types. OPN is up-regulated by pro-inflammatory cytokines such as TNF- $\alpha$ or TGF- $\beta$ and has been shown to play critical roles in inflammation and tissue repair of several organs. The diversity of OPN functions has been related to its extensive post-translational modifications and interactions with various integrin and CD44 receptors, mediating cell activation, cell attachment and immune system modulation (57-59).

Many recent studies have focused on the implication of OPN in hepatic fibrosis. In several of these studies, OPN deficiency or neutralization protected from progression of fibrosis in various mouse models $(57,58)$. Pritchett et al. showed that the transcription factor SOX9 controls the up-regulation of OPN in HSCs in rodent and human hepatic fibrosis (59). In a recent study, OPN was shown to promote the acetylation of nuclear HMGB1 and translocation to the cytoplasm leading to enhanced collagen I expression in HSCs (60). A clinical study on a large group of $\mathrm{HCV}$ patients revealed that serum OPN levels were progressively increased and correlated with the progression of fibrosis, indicating its potential use as a prognostic factor (61). On the other hand, OPN or OPN-related signaling pathways were shown to participate in liver regeneration after partial heparectomy and have protective role in experimental alcoholic hepatitis $(62,63)$. 
OPN has been also shown to affect the progression of cardiac, renal, pulmonary and muscle fibrosis. In a recent clinical study, OPN was found increased in the fibrotic tissue and plasma of patients with calcific aortic valve disease and it was shown to function by directly inhibiting the proliferation of cultured endothelial and valvular interstitial cells of aortic valves (64). In a chronic cardiac fibrosis model, OPN was necessary for the AP1-mediated induction of pro-fibrotic miR-21 (65). On the contrary, OPN was found to be protective in AMI models, either by promoting fibroblast migration and collagen expression through its Nterminal domain, or by inducing antioxidative mediators, chemokines and cardiomyocyte contraction $(66,67)$. In animal models of renal fibrosis, OPN was expressed by injured epithelial cells and it was shown to be regulated by transcriptional activation through AP-1 and to enhance the macrophage recruitment and the pro-fibrotic phenotype of pericytes (6871). White et al. showed that the serum levels of OPN could function as biomarker in pulmonary fibrosis by distinguishing IPF patients from alternatively idiopathic ones (72). Moreover, OPN was recently shown to play a role in the phenotypic polarization of inflammatory cells; in bleomycin-induced pulmonary fibrosis, OPN promoted the disease by inducing the Th17 and inhibiting the Th1 differentiation, while in a muscle degeneration model OPN ablation reduced fibrosis and improved muscle strength by changing macrophage polarization to a pro-regenerative M2c phenotype $(73,74)$.

\section{Tenascins}

Tenascins are a family of large oligomeric ECM glycoproteins consisting of four members, tenascin $\mathrm{C}, \mathrm{X}, \mathrm{R}$ and $\mathrm{W}$, with similar characteristics but differing expression patterns $(75,76)$. Among them, tenascin $\mathrm{C}$ (TN-C) has been mostly associated with fibrotic and tissue remodeling conditions, since contrary to the other family members it shows limited expression in adult tissues but is de novo induced after injury. TN-C has been shown to 
interact via its multiple domains with several cell-surface receptors including integrins $\alpha 9 \beta 1$, $\alpha \mathrm{v} \beta 3, \alpha \mathrm{v} \beta 6$, and toll-like receptor 4 (TLR-4), controlling cell adhesion, motility, proliferation, differentiation and survival.

While several past studies showed the up-regulation of TN-C and examined its role in fibrotic diseases of various organs (75), recent research has been mostly focused on the identification of $\mathrm{TN}-\mathrm{C}$ as biomarker for disease progression. In cardiac disease, re-expression of the fetal splicing variant $\mathrm{B}+\mathrm{TN}-\mathrm{C}$ in the heart or serum was correlated with signs of rejection of transplanted subjects or decreased survival and increased risk to undergo transplantation in a group of dilated cardiomyopathy patients $(77,78)$. High TN-C serum levels were shown to predict a greater incidence of maladaptive cardiac remodeling and worse prognosis in AMI patients (79). Moreover, TN-C was suggested as a marker to distinguish inflammatory cardiomyopathy from other types of cardiac disease, which would improve the management of patients (76). Another recent study showed that TN-C promotes inflammation by inducing macrophage migration and secretion of pro-inflammatory cytokines through activation of integrin av $\beta 3$, subsequent phosphorylation of FAK and nuclear translocation of $\mathrm{NF \kappa B}(80)$.

High TN-C levels were also detected in serum and biopsy samples from patients with scleroderma and in fibrotic skin of mice $(81,82)$. Secreted TN-C was described to act through TLR-4 in a mouse model of scleroderma to stimulate collagen expression and myofibroblast transformation. Similarly, TN-C was shown to affect hepatic fibrosis by stimulating HSCs to increase production of collagen I through signaling via integrin a9 $\beta 1$ (83). In idiopathic interstitial lung diseases, TN-C was found up-regulated both in fibroblasts and alveolar epithelial cells of patients and was shown to mediate TGF- $\beta$-induced collagen deposition and Smad signaling (84-86). Moreover, fibroblasts lacking TN-C have an increased capacity to 
digest fibrin which could explain the correlation of TN-C and fibrin deposition in several fibrotic disorders (87). A recent interesting study proposed a novel role for TN-C as an important component of the fibrogenic niche which facilitates fibroblast proliferation and expansion of fibrosis. The authors showed that TN-C was produced by fibroblasts and localized in fibrogenic foci in two models of kidney fibrosis, while it induced fibroblast proliferation and activation of proliferation-related genes through an integrin/FAK/mitogenactivated protein kinase pathway, both in vivo and in vitro (88).

\section{SPARC}

SPARC is a collagen-binding protein secreted by various cell types into the ECM. Several studies have reported elevated expression of SPARC in fibrosis of many tissues including heart, lung, skin, kidney and liver, showing that absence of SPARC results in significant attenuation of ECM deposition. SPARC has been described to function by binding to procollagen which inhibits its interaction with cell-surface receptors and stimulates collagen processing and incorporation into insoluble fibers $(89,90)$.

In a recent study, SPARC deletion attenuated myocardial stiffness and collagen content in aged mice attributed to decreased expression and activity of ADAMTS1 metalloproteinase (91). Apart from its high expression by fibroblasts during organ fibrosis, SPARC was also found to be produced by circulating inflammatory cells, mainly macrophages, regulating their extravasation into the fibrotic interstitium of heart and lung (90). Sangaletti et al. proposed a differential function of SPARC in fibroblasts and macrophages in a model of bleomycininduced lung fibrosis; using SPARC depleted mice and bone marrow chimeras, they found that SPARC expression by fibroblasts was required to induce collagen deposition, while SPARC depletion from macrophages caused exacerbated inflammation and fibrosis because 
of their inability to downregulate TNF-a production (92). In another study, SPARC was required for $\mathrm{H}_{2} \mathrm{O}_{2}$ production by lung fibroblasts after TGF- $\beta 1$ treatment, while SPARC knock-down in fibroblasts attenuated epithelial cell injury in a co-culture system (93). In liver fibrosis SPARC is upregulated in activated HSCs and mediates their migration towards TGF$\beta 1$ and TGF- $\beta 1$ secretion (94). Aseer et al. recently showed a differential expression of SPARC in liver and pancreas of streptozotocin-induced diabetic rats; SPARC was upregulated in the liver accompanied by TGF- $\beta 1$ induction and elevated fibrogenesis, while it was downregulated in the pancreas accompanied by chronic inflammation and strong expression of inflammatory genes (95). Increased SPARC expression in the bone marrow stroma was also shown to contribute to myelofibrosis, while its deficiency induced an enhanced myeloproliferative response (96). Interestingly, a recent study showed that SPARC siRNA could be encapsulated in nanoparticles leading to a significant target gene knock-down in cultured cells without any cytotoxicity, introducing a novel technology for the targeted inhibition of SPARC to treat fibrosis (97).

\section{Matricellular proteins as biomarkers or therapeutic targets of fibrosis}

Several studies have explored the utility of matricellular proteins as biomarkers both in animal and human biofluids and tissue samples, while their potential as targets of therapy has mostly been examined in animal models of fibrosis to date. In pulmonary fibrosis or asthmatic patients, serum Postn levels could efficiently predict a worsened outcome or resistance to therapy $(41,42)$. Moreover, plasma levels of OPN cound distinguish subgroups of lung disease patients (72). In terms of therapy, adenoviral CCN5 overexpression or treatment with a blocking antibody against Postn limited collagen deposition in IPF mouse models $(18,40)$. In several studies, increased serum TN-C levels in cardiac disease patients were associated with worse prognosis, adverse cardiac remodeling and increased risk to undergo 
transplantation (77-79). Cardiac overexpression of CCN5 or antibody targeting of Postn preserved cardiac function and decreased myocardial fibrosis $(5,37)$. Interestingly, normalization of matricellular protein expression by aldosterone receptor antagonism, further improved cardiac structure and function in addition to standard pharmacological heart failure therapy (98). In liver disease patients increased serum OPN levels correlated with the degree of fibrosis, while OPN neutralization in mice protected from liver fibrosis progression (58, 61). CCN1 delivery via tail vein could also attenuate hepatic fibrosis (13). In animal models of kidney fibrosis, delivery of recombinant CCN3 or antisense targeting of Postn could ameliorate the progression of the disease $(6,44,45)$. Elevated serum and tissue levels of TN$\mathrm{C}$ were associated with increased number of lesions and higher skin thickness in scleroderma patients $(81,82)$. In a mouse model of choroidal fibrosis, new generation RNA interference against Postn could inhibit fibrosis formation (56). Of note, pharmaceutical industries are becoming interested in the development of matricellular protein-based drugs to treat fibrosis, with few molecules currently in preclinical or clinical studies (6). The recent utilization of matricellular proteins as markers or targets of therapy in clinical studies and models of fibrosis is summarized in Table 1.

\section{Conclusions}

Since their identification matricellular proteins have evolved as crucial players in fibrotic diseases which renders them intriguing therapeutic targets. The last years large amounts of knowledge have been obtained on the differential function of these proteins as mediators or inhibitors of the progression of fibrosis in nearly every body organ, denoting their value as biomarkers or targets in a variety of therapeutic strategies. Notably, although they share common characteristics, several of these proteins were found to serve distinct functions in different disease contexts, suggesting that the use of matricellular proteins for prognostic or 
therapeutic purposes should be targeted and dependent on the disease background. These studies have contributed to our deeper understanding of the various roles of matricellular proteins and paved the way for the development of convenient detection systems or efficient drugs targeting matricellular proteins for future use in fibrosis patients.

\section{References}

Papers of particular interest, published recently, have been highlighted as:

- Of importance

1. Bornstein P. Matricellular proteins: an overview. J Cell Commun Signal 2009:3:163-5. Doi: 10.1007/s12079-009-0069-z.

2. Murphy-Ullrich JE, Sage EH. Revisiting the matricellular concept. Matrix Biol 2014:37:114. Doi: 10.1016/j.matbio.2014.07.005.

3. Gurtner GC, Werner S, Barrandon Y, Longaker MT. Wound repair and regeneration. Nature 2008:453:314-21. Doi: 10.1038/nature07039.

4. Jun JI, Lau LF. Taking aim at the extracellular matrix: CCN proteins as emerging therapeutic targets. Nat Rev Drug Discov 2011:10:945-63. Doi: 10.1038/nrd3599.

5. Díez J, González A, Ravassa S. Understanding the Role of CCN Matricellular Proteins in Myocardial Fibrosis. J Am Coll Cardiol 2016:67:1569-71. Doi: 10.1016/j.jacc.2016.01.029.

6. - Riser BL, Barnes JL, Varani J. Balanced regulation of the CCN family of matricellular proteins: a novel approach to the prevention and treatment of fibrosis and cancer. $\mathrm{J}$ Cell Commun Signal 2015:9:327-39. Doi: 10.1007/s12079-015-0309-3. This review discusses a novel approach of how combination of protein targeting can assist in treatment of fibrosis. 
7. Mason RM. Fell-Muir lecture: Connective tissue growth factor (CCN2) -- a pernicious and pleiotropic player in the development of kidney fibrosis. Int J Exp Pathol 2013:94:1-16. Doi: 10.1111/j.1365-2613.2012.00845.x.

8. Morales MG, Gutierrez J, Cabello-Verrugio C, Cabrera D, Lipson KE, Goldschmeding R, et al. Reducing CTGF/CCN2 slows down mdx muscle dystrophy and improves cell therapy. Hum Mol Genet 2013:22:4938-51. Doi: 10.1093/hmg/ddt352.

9. Morales MG, Cabrera D, Céspedes C, Vio CP, Vazquez Y, Brandan E, et al. Inhibition of the angiotensin-converting enzyme decreases skeletal muscle fibrosis in dystrophic mice by a diminution in the expression and activity of connective tissue growth factor (CTGF/CCN-2). Cell Tissue Res 2013:353:173-87. Doi: 10.1007/s00441-013-1642-6.

10. - Tank J, Lindner D, Wang X, Stroux A, Gilke L, Gast M, et al. Single-target RNA interference for the blockade of multiple interacting proinflammatory and profibrotic pathways in cardiac fibroblasts. J Mol Cell Cardiol 2014:66:141-56. Doi: 10.1016/j.yjmcc.2013.11.004. This article demonstrates the importance of selecting the correct target in order to maximize the beneficial effects of treatment.

11. Borkham-Kamphorst E, Steffen BT, Van de Leur E, Haas U, Tihaa L, Friedman SL, et al. CCN1/CYR61 overexpression in hepatic stellate cells induces ER stress-related apoptosis. Cell Signal 2016:28:34-42. Doi: 10.1016/j.cellsig.2015.10.013.

12. Borkham-Kamphorst E, Schaffrath C, Van de Leur E, Haas U, Tihaa L, Meurer SK, et al. The anti-fibrotic effects of CCN1/CYR61 in primary portal myofibroblasts are mediated through induction of reactive oxygen species resulting in cellular senescence, apoptosis and attenuated TGF- $\beta$ signaling. Biochim Biophys Acta 2014:1843:902-14. Doi: 10.1016/j.bbamcr.2014.01.023. 
13. Kim KH, Chen CC, Monzon RI, Lau LF. Matricellular protein CCN1 promotes regression of liver fibrosis through induction of cellular senescence in hepatic myofibroblasts. Mol Cell Biol 2013:33:2078-90. Doi: 10.1128/MCB.00049-13.

14. Grazioli S, Gil S, An D, Kajikawa O, Farnand AW, Hanson JF, et al. CYR61 (CCN1) overexpression induces lung injury in mice. Am J Physiol Lung Cell Mol Physiol 2015:308:L759-65. Doi: 10.1152/ajplung.00190.2014.

15. Borkham-Kamphorst E, van Roeyen CR, Van de Leur E, Floege J, Weiskirchen R. CCN3/NOV small interfering RNA enhances fibrogenic gene expression in primary hepatic stellate cells and cirrhotic fat storing cell line CFSC. J Cell Commun Signal 2012:6:11-25. Doi: 10.1007/s12079-011-0141-3.

16. Marchal PO, Kavvadas P, Abed A, Kazazian C, Authier F, Koseki H, et al. Reduced NOV/CCN3 Expression Limits Inflammation and Interstitial Renal Fibrosis after Obstructive Nephropathy in Mice. PLoS One 2015:10:e0137876. Doi: 10.1371/journal.pone.0137876.

17. Xu H, Liu C, Sun Z, Guo X, Zhang Y, Liu M, et al. CCN5 attenuates profibrotic phenotypes of fibroblasts through the Smad6-CCN2 pathway: Potential role in epidural fibrosis. Int J Mol Med 2015:36:123-9. Doi: 10.3892/ijmm.2015.2190.

18. Zhang L, Li Y, Liang C, Yang W. CCN5 overexpression inhibits profibrotic phenotypes via the PI3K/Akt signaling pathway in lung fibroblasts isolated from patients with idiopathic pulmonary fibrosis and in an in vivo model of lung fibrosis. Int J Mol Med 2014:33:478-86. Doi: $10.3892 /$ ijmm.2013.1565.

19. - Kim DJ, Christofidou ED, Keene DR, Hassan Milde M, Adams JC. Intermolecular interactions of thrombospondins drive their accumulation in extracellular matrix. Mol Biol Cell 2015:26:2640-54. Doi: 10.1091/mbc.E14-05-0996. This was the first study to describe a novel mechanism of how intermolecular interactions of a matricellular protein affect its deposition into the matrix. 
20. Zeisberg M, Tampe B, LeBleu V, Tampe D, Zeisberg EM, Kalluri R. Thrombospondin-1 deficiency causes a shift from fibroproliferative to inflammatory kidney disease and delays onset of renal failure. Am J Pathol 2014:184:2687-98. Doi: 10.1016/j.ajpath.2014.06.014.

21. Cui W, Maimaitiyiming H, Qi X, Norman H, Wang S. Thrombospondin 1 mediates renal dysfunction in a mouse model of high-fat diet-induced obesity. Am J Physiol Renal Physiol 2013:305:F871-80. Doi: 10.1152/ajprenal.00209.2013.

22. Bige N, Shweke N, Benhassine S, Jouanneau C, Vandermeersch S, Dussaule JC, et al. Thrombospondin-1 plays a profibrotic and pro-inflammatory role during ureteric obstruction. Kidney Int 2012:81:1226-38. Doi: 10.1038/ki.2012.21.

23. Sun D, Ma Y, Han H, Yin Z, Liu C, Feng J, et al. Thrombospondin-1 short hairpin RNA suppresses tubulointerstitial fibrosis in the kidney of ureteral obstruction by ameliorating peritubular capillary injury. Kidney Blood Press Res 2012:35:35-47. Doi: $10.1159 / 000330718$.

24. Inoue M, Jiang Y, Barnes RH 2nd, Tokunaga M, Martinez-Santibañez G, Geletka L, et al. Thrombospondin 1 mediates high-fat diet-induced muscle fibrosis and insulin resistance in male mice. Endocrinology 2013:154:4548-59. Doi: 10.1210/en.2013-1587.

25. Gonzalez-Quesada C, Cavalera M, Biernacka A, Kong P, Lee DW, Saxena A, et al. Thrombospondin-1 induction in the diabetic myocardium stabilizes the cardiac matrix in addition to promoting vascular rarefaction through angiopoietin-2 upregulation. Circ Res 2013:113:1331-44. Doi: 10.1161/CIRCRESAHA.113.302593.

26. Reinecke H, Robey TE, Mignone JL, Muskheli V, Bornstein P, Murry CE. Lack of thrombospondin-2 reduces fibrosis and increases vascularity around cardiac cell grafts. Cardiovasc Pathol 2013:22:91-5. Doi: 10.1016/j.carpath.2012.03.005. 
27. Pohjolainen V, Mustonen E, Taskinen P, Näpänkangas J, Leskinen H, Ohukainen P, et al. Increased thrombospondin-2 in human fibrosclerotic and stenotic aortic valves. Atherosclerosis 2012:220:66-71. Doi: 10.1016/j.atherosclerosis.2011.10.003.

28. Kajihara I, Jinnin M, Yamane K, Makino T, Honda N, Igata $\mathrm{T}$, et al. Increased accumulation of extracellular thrombospondin-2 due to low degradation activity stimulates type I collagen expression in scleroderma fibroblasts. Am J Pathol 2012:180:703-14. Doi: 10.1016/j.ajpath.2011.10.030.

29. van Almen GC, Swinnen M, Carai P, Verhesen W, Cleutjens JP, D'hooge J, et al. Absence of thrombospondin-2 increases cardiomyocyte damage and matrix disruption in doxorubicininduced cardiomyopathy. J Mol Cell Cardiol 2011:51:318-28. Doi: 10.1016/j.yjmcc.2011.05.010.

30. Horiuchi K, Amizuka N, Takeshita S, Takamatsu H, Katsuura M, Ozawa H, et al. Identification and characterization of a novel protein, periostin, with restricted expression to periosteum and periodontal ligament and increased expression by transforming growth factor beta. J Bone Miner Res 1999:14:1239-49. Doi: 10.1359/jbmr.1999.14.7.1239.

31. Oka T, Xu J, Kaiser RA, Melendez J, Hambleton M, Sargent MA, et al. Genetic manipulation of periostin expression reveals a role in cardiac hypertrophy and ventricular remodeling. Circ Res 2007:101:313-21. Doi: 10.1161/CIRCRESAHA.107.149047.

32. Shimazaki M, Nakamura K, Kii I, Kashima T, Amizuka N, Li M, et al. Periostin is essential for cardiac healing after acute myocardial infarction. J Exp Med 2008:205:295-303. Doi: $10.1084 /$ jem.20071297.

33. Wu H, Li GN, Xie J, Li R, Chen QH, Chen JZ, et al. Resveratrol ameliorates myocardial fibrosis by inhibiting ROS/ERK/TGF- $\beta$ /periostin pathway in STZ-induced diabetic mice. BMC Cardiovasc Disord 2016:16:5. Doi: 10.1186/s12872-015-0169-z. 
34. Guan J, Liu WQ, Xing MQ, Shi Y, Tan XY, Jiang CQ, et al. Elevated expression of periostin in diabetic cardiomyopathy and the effect of valsartan. BMC Cardiovasc Disord 2015:15:90. Doi: 10.1186/s12872-015-0084-3.

35. Wu H, Chen L, Xie J, Li R, Li GN, Chen QH, et al. Periostin expression induced by oxidative stress contributes to myocardial fibrosis in a rat model of high salt-induced hypertension. Mol Med Rep 2016:14:776-82. Doi: 10.3892/mmr.2016.5308.

36. Kaur H, Takefuji M, Ngai CY, Carvalho J, Bayer J, Wietelmann A, et al. Targeted Ablation of Periostin-Expressing Activated Fibroblasts Prevents Adverse Cardiac Remodeling in Mice. Circ Res 2016:118:1906-17. Doi: 10.1161/CIRCRESAHA.116.308643.

37. - Taniyama Y, Katsuragi N, Sanada F, Azuma J, Iekushi K, Koibuchi N, et al. Selective Blockade of Periostin Exon 17 Preserves Cardiac Performance in Acute Myocardial Infarction. Hypertension 2016:67:356-61. Doi: 10.1161/HYPERTENSIONAHA.115.06265. Excellent demonstration of how a targeted intervention leads to an effective treatment.

38. Sidhu SS, Yuan S, Innes AL, Kerr S, Woodruff PG, Hou L, et al. Roles of epithelial cellderived periostin in TGF-beta activation, collagen production, and collagen gel elasticity in asthma. Proc Natl Acad Sci U S A 2010:107:14170-5. Doi: 10.1073/pnas.1009426107.

39. Uchida M, Shiraishi H, Ohta S, Arima K, Taniguchi K, Suzuki S, et al. Periostin, a matricellular protein, plays a role in the induction of chemokines in pulmonary fibrosis. Am J Respir Cell Mol Biol 2012:46:677-86. Doi: 10.1165/rcmb.2011-0115OC.

40. Naik PK, Bozyk PD, Bentley JK, Popova AP, Birch CM, Wilke CA, et al. Periostin promotes fibrosis and predicts progression in patients with idiopathic pulmonary fibrosis. Am J Physiol Lung Cell Mol Physiol 2012:303:L1046-56. Doi: 10.1152/ajplung.00139.2012.

41. - Tajiri M, Okamoto M, Fujimoto K, Johkoh T, Ono J, Tominaga M, et al. Serum level of periostin can predict long-term outcome of idiopathic pulmonary fibrosis. Respir Investig 
2015:53:73-81. Doi: 10.1016/j.resinv.2014.12.003. Important demonstration of the utility of a matricellular protein for prediction of long-term outcomes in patients.

42. - Izuhara K, Matsumoto H, Ohta S, Ono J, Arima K, Ogawa M. Recent developments regarding periostin in bronchial asthma. Allergol Int 2015:64 Suppl:S3-10. Doi: 10.1016/j.alit.2015.04.012. This study was the first to establish periostin as a read-out protein for the efficiency of a certain class of drugs in the treatment of asthma.

43. Guerrot D, Dussaule JC, Mael-Ainin M, Xu-Dubois YC, Rondeau E, Chatziantoniou C, et al. Identification of periostin as a critical marker of progression/reversal of hypertensive nephropathy. PLoS One 2012:7:e31974.

44. Mael-Ainin M, Abed A, Conway SJ, Dussaule JC, Chatziantoniou C. Inhibition of periostin expression protects against the development of renal inflammation and fibrosis. $\mathrm{J}$ Am Soc Nephrol 2014:25:1724-36. Doi: 10.1681/ASN.2013060664.

45. Prakoura N, Kavvadas P, Kormann R, Dussaule JC, Chadjichristos C, Chatziantoniou C. NFאB-Induced Periostin Activates Integrin- $\beta 3$ Signaling to Promote Renal Injury in GN. J Am Soc Nephrol 2016 Dec 5. pii: ASN.2016070709.

46. Sen K, Lindenmeyer MT, Gaspert A, Eichinger F, Neusser MA, Kretzler M, et al. Periostin is induced in glomerular injury and expressed de novo in interstitial renal fibrosis. Am J Pathol 2011:179:1756-67. Doi: 10.1016/j.ajpath.2011.06.002.

47. Satirapoj B, Tassanasorn S, Charoenpitakchai M, Supasyndh O. Periostin as a tissue and urinary biomarker of renal injury in type 2 diabetes mellitus. PLoS One 2015:10:e0124055. Doi: 10.1371/journal.pone.0124055.

48. Wantanasiri P, Satirapoj B, Charoenpitakchai M, Aramwit P. Periostin: a novel tissue biomarker correlates with chronicity index and renal function in lupus nephritis patients. Lupus 2015:24:835-45. Doi: 10.1177/0961203314566634. 
49. Wallace DP, White C, Savinkova L, Nivens E, Reif GA, Pinto CS, et al. Periostin promotes renal cyst growth and interstitial fibrosis in polycystic kidney disease. Kidney Int 2014:85:845-54. Doi: 10.1038/ki.2013.488.

50. Zhou HM, Wang J, Elliott C, Wen W, Hamilton DW, Conway SJ. Spatiotemporal expression of periostin during skin development and incisional wound healing: lessons for human fibrotic scar formation. J Cell Commun Signal 2010:4:99-107. Doi: 10.1007/s12079010-0090-2.

51. Yang L, Serada S, Fujimoto M, Terao M, Kotobuki Y, Kitaba S, et al. Periostin facilitates skin sclerosis via PI3K/Akt dependent mechanism in a mouse model of scleroderma. PLoS One 2012:7:e41994. Doi: 10.1371/journal.pone.0041994.

52. Lorts A, Schwanekamp JA, Baudino TA, McNally EM, Molkentin JD. Deletion of periostin reduces muscular dystrophy and fibrosis in mice by modulating the transforming growth factor- $\beta$ pathway. Proc Natl Acad Sci U S A 2012:109:10978-83. Doi: 10.1073/pnas.1204708109.

53. Hong L, Shejiao D, Fenrong C, Gang Z, Lei D. Periostin down-regulation attenuates the pro-fibrogenic response of hepatic stellate cells induced by TGF- $\beta 1$. J Cell Mol Med 2015:19:2462-8. Doi: 10.1111/jcmm.12636.

54. Sugiyama A, Kanno K, Nishimichi N, Ohta S, Ono J, Conway SJ, et al. Periostin promotes hepatic fibrosis in mice by modulating hepatic stellate cell activation via $\alpha v$ integrin interaction. J Gastroenterol 2016. Doi: 10.1007/s00535-016-1206-0.

55. - Ozdemir C, Akpulat U, Sharafi P, Yıldız Y, Onbaşılar I, Kocaefe C. Periostin is temporally expressed as an extracellular matrix component in skeletal muscle regeneration and differentiation. Gene 2014:553:130-9. Doi: 10.1016/j.gene.2014.10.014. Important demonstration that a matricellular protein can promote tissue regeneration in the context of matrix remodeling. 
56. • Nakama T, Yoshida S, Ishikawa K, Kobayashi Y, Zhou Y, Nakao S, et al. Inhibition of choroidal fibrovascular membrane formation by new class of RNA interference therapeutic agent targeting periostin. Gene Ther 2015:22:127-37. Doi: 10.1038/gt.2014.112. Excellent highlight of how the evolution of drug manufacturing technology can promote therapeutic efficiency.

57. Lancha A, Rodríguez A, Catalán V, Becerril S, Sáinz N, Ramírez B, et al. Osteopontin deletion prevents the development of obesity and hepatic steatosis via impaired adipose tissue matrix remodeling and reduced inflammation and fibrosis in adipose tissue and liver in mice. PLoS One 2014:9:e98398. Doi: 10.1371/journal.pone.0098398.

58. Coombes JD, Swiderska-Syn M, Dollé L, Reid D, Eksteen B, Claridge L, et al. Osteopontin neutralisation abrogates the liver progenitor cell response and fibrogenesis in mice. Gut 2015:64:1120-31. Doi: 10.1136/gutjnl-2013-306484.

59. Pritchett J, Harvey E, Athwal V, Berry A, Rowe C, Oakley F, et al. Osteopontin is a novel downstream target of SOX9 with diagnostic implications for progression of liver fibrosis in humans. Hepatology 2012:56:1108-16. Doi: 10.1002/hep.25758.

60. Arriazu E, Ge X, Leung TM, Magdaleno F, Lopategi A, Lu Y, et al. Signalling via the osteopontin and high mobility group box-1 axis drives the fibrogenic response to liver injury. Gut 2016. Doi: 10.1136/gutjnl-2015-310752.

61. Matsue Y, Tsutsumi M, Hayashi N, Saito T, Tsuchishima M, Toshikuni N, et al. Serum osteopontin predicts degree of hepatic fibrosis and serves as a biomarker in patients with hepatitis C virus infection. PLoS One 2015:10:e0118744. Doi: 10.1371/journal.pone.0118744.

62. Wang G, Chen S, Zhao C, Li X, Zhang L, Zhao W, et al. Gene expression profiles predict the possible regulatory role of OPN-mediated signaling pathways in rat liver regeneration. Gene 2016:576:782-90. Doi: 10.1016/j.gene.2015.11.008. 
63. Lazaro R, Wu R, Lee S, Zhu NL, Chen CL, French SW, et al. Osteopontin deficiency does not prevent but promotes alcoholic neutrophilic hepatitis in mice. Hepatology 2015:61:12940. Doi: 10.1002/hep.27383.

64. Passmore M, Nataatmadja M, Fung YL, Pearse B, Gabriel S, Tesar P, et al. Osteopontin alters endothelial and valvular interstitial cell behavior in calcific aortic valve stenosis through HMGB1 regulation. Eur J Cardiothorac Surg 2015:48:e20-9. Doi: 10.1093/ejcts/ezv244.

65. Lorenzen JM, Schauerte C, Hübner A, Kölling M, Martino F, Scherf K, et al. Osteopontin is indispensible for AP1-mediated angiotensin II-related miR-21 transcription during cardiac fibrosis. Eur Heart J 2015:36:2184-96. Doi: 10.1093/eurheartj/ehv109.

66. Uchinaka A, Hamada Y, Mori S, Miyagawa S, Saito A, Sawa Y, et al. SVVYGLR motif of the thrombin-cleaved N-terminal osteopontin fragment enhances the synthesis of collagen type III in myocardial fibrosis. Mol Cell Biochem 2015:408:191-203. Doi: 10.1007/s11010$015-2495-y$

67. Duerr GD, Mesenholl B, Heinemann JC, Zoerlein M, Huebener P, Schneider P, et al. Cardioprotective effects of osteopontin-1 during development of murine ischemic cardiomyopathy. Biomed Res Int 2014:2014:124063. Doi: 10.1155/2014/124063.

68. Yano R, Golbar HM, Izawa T, Sawamoto O, Kuwamura M, Yamate J. Participation of bone morphogenetic protein (BMP)-6 and osteopontin in cisplatin (CDDP)-induced rat renal fibrosis. Exp Toxicol Pathol 2015:67:99-107. Doi: 10.1016/j.etp.2014.10.002.

69. Kashiwagi E, Tonomura Y, Kondo C, Masuno K, Fujisawa K, Tsuchiya N, et al. Involvement of neutrophil gelatinase-associated lipocalin and osteopontin in renal tubular regeneration and interstitial fibrosis after cisplatin-induced renal failure. Exp Toxicol Pathol 2014:66:301-11. Doi: 10.1016/j.etp.2014.04.007. 
70. Tachibana H, Ogawa D, Matsushita Y, Bruemmer D, Wada J, Teshigawara S, et al. Activation of liver $\mathrm{X}$ receptor inhibits osteopontin and ameliorates diabetic nephropathy. $\mathrm{J}$ Am Soc Nephrol 2012:23:1835-46. Doi: 10.1681/ASN.2012010022.

71. Tan TK, Zheng G, Hsu TT, Lee SR, Zhang J, Zhao Y, et al. Matrix metalloproteinase-9 of tubular and macrophage origin contributes to the pathogenesis of renal fibrosis via macrophage recruitment through osteopontin cleavage. Lab Invest 2013:93:434-49. Doi: 10.1038/labinvest.2013.3.

72. White ES, Xia M, Murray S, Dyal R, Flaherty CM, Flaherty KR, et al. Plasma Surfactant Protein-D, Matrix Metalloproteinase-7, and Osteopontin Index Distinguishes Idiopathic Pulmonary Fibrosis From Other Idiopathic Interstitial Pneumonias. Am J Respir Crit Care Med 2016. Doi: 10.1164/rccm.201505-0862OC.

73. Oh K, Seo MW, Kim YW, Lee DS. Osteopontin Potentiates Pulmonary Inflammation and Fibrosis by Modulating IL-17/IFN- $\gamma$-secreting T-cell Ratios in Bleomycin-treated Mice. Immune Netw 2015:15:142-9. Doi: 10.4110/in.2015.15.3.142.

74. - Capote J, Kramerova I, Martinez L, Vetrone S, Barton ER, Sweeney HL, et al. Osteopontin ablation ameliorates muscular dystrophy by shifting macrophages to a proregenerative phenotype. J Cell Biol 2016:213:275-88. Doi: 10.1083/jcb.201510086. Together with the paper of Bradshaw, this study interestingly demonstrates that matricellular proteins can affect fibrosis through direct effects on immune cell phenotypes.

75. Kasprzycka M, Hammarström C, Haraldsen G. Tenascins in fibrotic disorders-from bench to bedside. Cell Adh Migr 2015:9:83-9. Doi: 10.4161/19336918.2014.994901.

76. Imanaka-Yoshida $\mathrm{K}$. Tenascin-C in cardiovascular tissue remodeling: from development to inflammation and repair. Circ J 2012:76:2513-20.

77. Franz M, Matusiak-Brückner M, Richter P, Grün K, Ziffels B, Neri D, et al. De novo expression of fetal $\mathrm{ED}-\mathrm{A}(+)$ fibronectin and $\mathrm{B}(+)$ tenascin-C splicing variants in human 
cardiac allografts: potential impact for targeted therapy of rejection. J Mol Histol 2014:45:519-32. Doi: 10.1007/s10735-014-9573-4.

78. Franz M, Berndt A, Neri D, Galler K, Grün K, Porrmann C, et al. Matrix metalloproteinase-9, tissue inhibitor of metalloproteinase- $1, \mathrm{~B}^{+}$tenascin-C and $\mathrm{ED}-\mathrm{A}^{+}$ fibronectin in dilated cardiomyopathy: potential impact on disease progression and patients' prognosis. Int J Cardiol 2013:168:5344-51. Doi: 10.1016/j.ijcard.2013.08.005.

79. Nishioka T, Onishi K, Shimojo N, Nagano Y, Matsusaka H, Ikeuchi M, et al. Tenascin-C may aggravate left ventricular remodeling and function after myocardial infarction in mice. Am J Physiol Heart Circ Physiol 2010:298:H1072-8. Doi: 10.1152/ajpheart.00255.2009.

80. Shimojo N, Hashizume R, Kanayama K, Hara M, Suzuki Y, Nishioka T, et al. Tenascin-C may accelerate cardiac fibrosis by activating macrophages via the integrin $\alpha \mathrm{V} \beta 3 /$ nuclear factor-kB/interleukin-6 axis. Hypertension 2015:66:757-66. Doi: 10.1161/HYPERTENSIONAHA.115.06004.

81. Inoue K, Jinnin M, Hara Y, Makino K, Kajihara I, Makino T, et al. Serum levels of tenascin-C in collagen diseases. J Dermatol 2013:40:715-9. Doi: 10.1111/1346-8138.12218.

82. Bhattacharyya S, Wang W, Morales-Nebreda L, Feng G, Wu M, Zhou X, et al. TenascinC drives persistence of organ fibrosis. Nat Commun 2016:7:11703. Doi: 10.1038/ncomms 11703.

83. Ma JC, Huang X, Shen YW, Zheng C, Su QH, Xu JK, et al. Tenascin-C promotes migration of hepatic stellate cells and production of type I collagen. Biosci Biotechnol Biochem 2016:80:1470-7. Doi: 10.1080/09168451.2016.1165600.

84. Estany S, Vicens-Zygmunt V, Llatjós R, Montes A, Penín R, Escobar I, et al. Lung fibrotic tenascin-C upregulation is associated with other extracellular matrix proteins and induced by TGF $\beta 1$. BMC Pulm Med 2014:14:120. Doi: 10.1186/1471-2466-14-120. 
85. Fitch PM, Howie SE, Wallace WA. Oxidative damage and TGF- $\beta$ differentially induce lung epithelial cell sonic hedgehog and tenascin-C expression: implications for the regulation of lung remodelling in idiopathic interstitial lung disease. Int J Exp Pathol 2011:92:8-17. Doi: 10.1111/j.1365-2613.2010.00743.x.

86. Carey WA, Taylor GD, Dean WB, Bristow JD. Tenascin-C deficiency attenuates TGF-ßmediated fibrosis following murine lung injury. Am J Physiol Lung Cell Mol Physiol 2010:299:L785-93. Doi: 10.1152/ajplung.00385.2009.

87. Brellier F, Hostettler K, Hotz HR, Ozcakir C, Çöloğlu SA, Togbe D, et al. Tenascin-C triggers fibrin accumulation by downregulation of tissue plasminogen activator. FEBS Lett 2011:585:913-20. Doi: 10.1016/j.febslet.2011.02.023.

88. - Fu H, Tian Y, Zhou L, Zhou D, Tan RJ, Stolz DB, et al. Tenascin-C Is a Major Component of the Fibrogenic Niche in Kidney Fibrosis. J Am Soc Nephrol 2016 Sep 9. pii: ASN.2016020165. Interesting demonstration of a novel function of tenascin- $C$ as an important component of the fibrogenic niche promoting fibroblast proliferation and expansion of fibrosis.

89. Trombetta-Esilva J, Bradshaw AD. The Function of SPARC as a Mediator of Fibrosis. Open Rheumatol J 2012:6:146-55. Doi: 10.2174/1874312901206010146.

90. - Bradshaw AD. The role of secreted protein acidic and rich in cysteine (SPARC) in cardiac repair and fibrosis: Does expression of SPARC by macrophages influence outcomes? J Mol Cell Cardiol 2016:93:156-61. Doi: 10.1016/j.yjmcc.2015.11.014. Together with the study of Capote et al., this paper interestingly demonstrates that matricellular proteins can affect fibrosis through direct effects on immune cell phenotypes.

91. Toba H, de Castro Brás LE, Baicu CF, Zile MR, Lindsey ML, Bradshaw AD. Increased ADAMTS1 mediates SPARC-dependent collagen deposition in the aging myocardium. Am J Physiol Endocrinol Metab 2016:310:E1027-35. Doi: 10.1152/ajpendo.00040.2016. 
92. Sangaletti S, Tripodo C, Cappetti B, Casalini P, Chiodoni C, Piconese S, et al. SPARC oppositely regulates inflammation and fibrosis in bleomycin-induced lung damage. Am J Pathol 2011:179:3000-10. Doi: 10.1016/j.ajpath.2011.08.027.

93. Shibata S, Ishiyama J. Secreted protein acidic and rich in cysteine (SPARC) is upregulated by transforming growth factor (TGF)- $\beta$ and is required for TGF- $\beta$-induced hydrogen peroxide production in fibroblasts. Fibrogenesis Tissue Repair 2013:6:6. Doi: 10.1186/1755-1536-6-6. 94. Atorrasagasti C, Aquino JB, Hofman L, Alaniz L, Malvicini M, Garcia M, et al. SPARC downregulation attenuates the profibrogenic response of hepatic stellate cells induced by TGF- $\beta 1$ and PDGF. Am J Physiol Gastrointest Liver Physiol 2011:300:G739-48. Doi: 10.1152/ajpgi.00316.2010.

95. Aseer KR, Kim SW, Choi MS, Yun JW. Opposite Expression of SPARC between the Liver and Pancreas in Streptozotocin-Induced Diabetic Rats. PLoS One 2015:10:e0131189. Doi: 10.1371/journal.pone.0131189.

96. Tripodo C, Sangaletti S, Guarnotta C, Piccaluga PP, Cacciatore M, Giuliano M, et al. Stromal SPARC contributes to the detrimental fibrotic changes associated with myeloproliferation whereas its deficiency favors myeloid cell expansion. Blood 2012:120:3541-54. Doi: 10.1182/blood-2011-12-398537.

97. Tan YF, Mundargi RC, Chen MH, Lessig J, Neu B, Venkatraman SS, et al. Layer-bylayer nanoparticles as an efficient siRNA delivery vehicle for SPARC silencing. Small 2014:10:1790-8. Doi: 10.1002/smll.201303201.

98. Muñoz-Pacheco P, Ortega-Hernández A, Caro-Vadillo A, Casanueva-Eliceiry S, Aragoncillo P, Egido J, Fernández-Cruz A, et al. Eplerenone enhances cardioprotective effects of standard heart failure therapy through matricellular proteins in hypertensive heart failure. J Hypertens 2013:31:2309-18. Doi: 10.1097/HJH.0b013e328364abd6. 


\section{Inflammation}

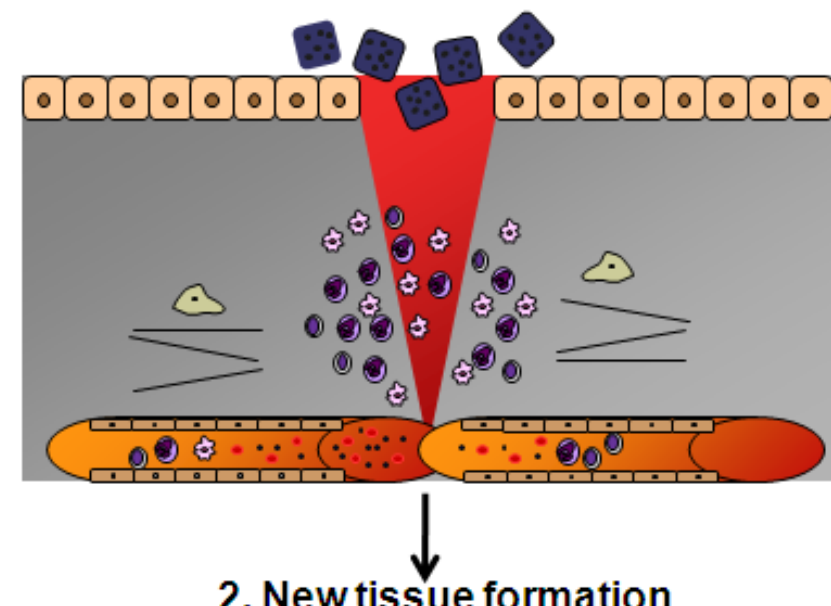

2. New tissue formation

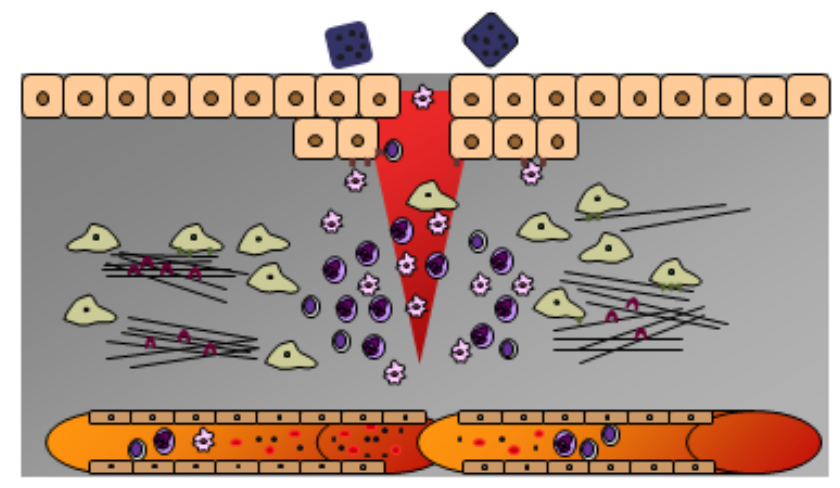

-

Epithelial cell

- Endothelial cell

S Fibroblast 3a. Remodeling

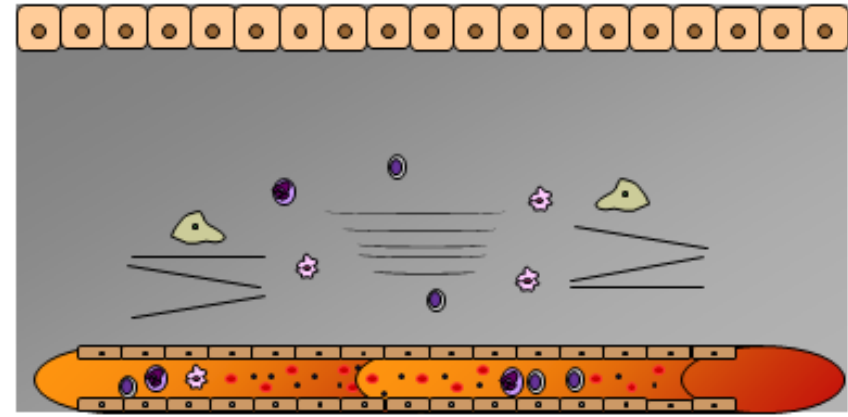

3b. Fibrosis

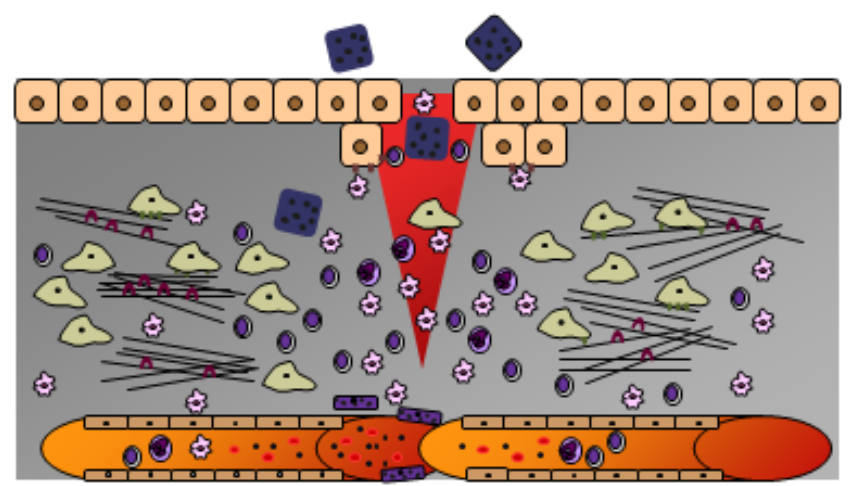

Apoptotic/necrotic cell

Figure 1. The process of wound healing can be divided into three distinct but highly overlapping phases: inflammation, new tissue formation and remodeling. When wound healing becomes chronic and establishment of the initial tissue architecture cannot be achieved, fibrosis may occur. The key components and cell types implicated in wound healing are illustrated. 


\begin{tabular}{|c|c|c|c|c|}
\hline Organ & Disease & $\begin{array}{c}\text { Matricellular } \\
\text { protein } \\
\text { involved }\end{array}$ & $\begin{array}{l}\text { Effect as biomarker or } \\
\text { therapeutic target }\end{array}$ & Reference \\
\hline \multirow[t]{5}{*}{ Lung } & Pulmonary fibrosis & POSTN & $\begin{array}{l}\text { Increased serum levels predict } \\
\text { worsened outcomes }\end{array}$ & 41 \\
\hline & Asthma & POSTN & $\begin{array}{l}\text { Increased serum levels predict } \\
\text { resistance to therapy }\end{array}$ & 42 \\
\hline & Pulmonary diseases & OPN & $\begin{array}{l}\text { Plasma levels distinguish } \\
\text { subgroups of patients }\end{array}$ & 72 \\
\hline & $\begin{array}{l}\text { Mouse model of bleomycin- } \\
\text { induced IPF }\end{array}$ & CCN5 & $\begin{array}{l}\text { Adenoviral CCN5 overexpression } \\
\text { limits collagen deposition }\end{array}$ & 18 \\
\hline & $\begin{array}{l}\text { Mouse model of bleomycin- } \\
\text { induced IPF }\end{array}$ & POSTN & $\begin{array}{l}\text { Treatment with blocking antibody } \\
\text { protects from disease progression }\end{array}$ & 40 \\
\hline \multirow[t]{5}{*}{ Heart } & Cardiac transplantation & TN-C & $\begin{array}{l}\text { Increased serum levels of } \mathrm{B}+ \\
\text { variant correlate with sings of } \\
\text { rejection and tissue inflammation }\end{array}$ & 77 \\
\hline & Dilated cardiomyopathy & TN-C & $\begin{array}{l}\text { Increased serum and tissue levels } \\
\text { of } \mathrm{B}+\text { variant associate with } \\
\text { decreased survival and increased } \\
\text { risk for transplantation }\end{array}$ & 78 \\
\hline & Myocardial Infarction & TN-C & $\begin{array}{l}\text { Increased serum levels predict } \\
\text { maladaptive remodeling and worse } \\
\text { prognosis }\end{array}$ & 79 \\
\hline & $\begin{array}{l}\text { Aortic constriction- induced } \\
\text { pressure overload in mice }\end{array}$ & CCN5 & $\begin{array}{l}\text { Cardiac overexpression reverses } \\
\text { established fibrosis }\end{array}$ & 5 \\
\hline & Rat model of AMI & POSTN & $\begin{array}{l}\text { Neutralizing antibody preserves } \\
\text { cardiac function and decreases } \\
\text { fibrosis }\end{array}$ & 37 \\
\hline \multirow[t]{3}{*}{ Liver } & $\begin{array}{l}\text { Hepatitis } \\
\text { infection }\end{array}$ & OPN & $\begin{array}{l}\text { Serum levels correlate with degree } \\
\text { of hepatic fibrosis }\end{array}$ & 61 \\
\hline & Mouse models of liver fibrosis & OPN & $\begin{array}{l}\text { Neutralizing aptamers or antibodies } \\
\text { protect from fibrosis progression }\end{array}$ & 58 \\
\hline & $\begin{array}{l}\mathrm{CCl}_{4} \text {-induced liver fibrosis in } \\
\text { mice }\end{array}$ & CCN1 & $\begin{array}{l}\text { Tail vein delivery of recombinant } \\
\text { protein accelerates fibrosis } \\
\text { regression }\end{array}$ & 13 \\
\hline \multirow[t]{2}{*}{ Kidney } & $\begin{array}{l}\text { Ob/ob mouse model of diabetic } \\
\text { nephropathy }\end{array}$ & $\mathrm{CCN} 3$ & $\begin{array}{l}\text { Intraperitoneal injections with } \\
\text { recombinant protein protect against } \\
\text { glomerular fibrosis and podocyte } \\
\text { loss }\end{array}$ & 6 \\
\hline & $\begin{array}{l}\text { L-name-induced hypertensive } \\
\text { nephropathy in rats, NTS-induced } \\
\text { glomerulonephritis in mice }\end{array}$ & POSTN & $\begin{array}{l}\text { Late antinsense treatment inhibits } \\
\text { or reverses established fibrosis }\end{array}$ & 44,45 \\
\hline Skin & Systemic sclerosis & TN-C & $\begin{array}{l}\text { Higher serum and tissue levels } \\
\text { associate with higher skin } \\
\text { thickness or incidence of ulcers }\end{array}$ & 81,82 \\
\hline Lens & $\begin{array}{l}\text { Laser-induced mouse model of } \\
\text { choroidal fibrosis }\end{array}$ & POSTN & 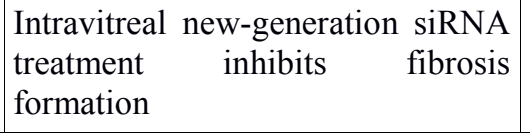 & 56 \\
\hline
\end{tabular}

Table 1. Assessment of matricellular proteins as markers or targets of therapy in fibrotic diseases. 